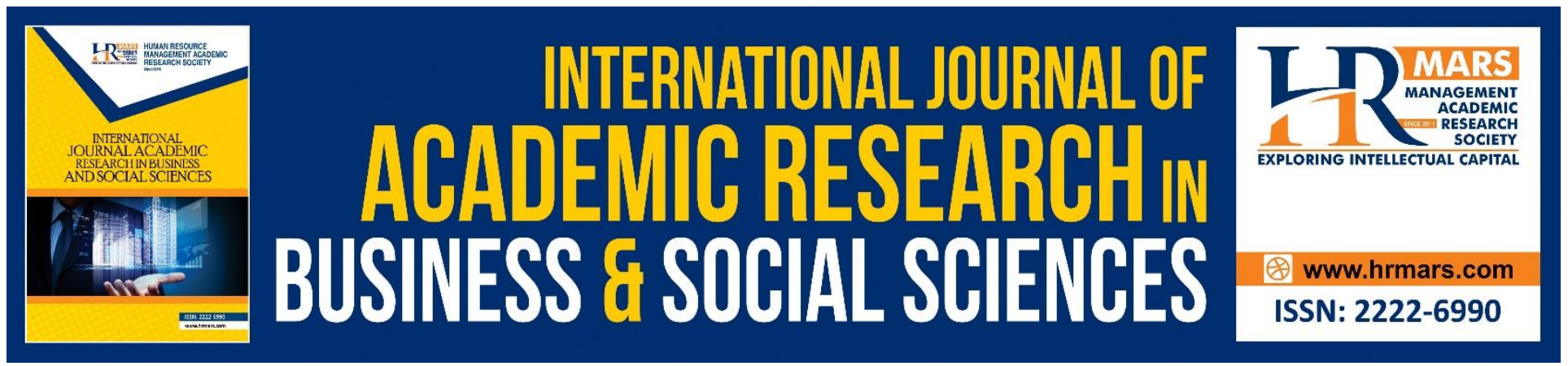

\title{
Motivation and Employee Retention among Millennials in Malaysia
}

\section{Ong Choon Hee and Loh Xin Rhung}

To Link this Article: http://dx.doi.org/10.6007/IJARBSS/v9-i2/5629

DOI: $\quad 10.6007 /$ IJARBSS/v9-i2/5629

Received: 10 Jan 2019, Revised: 23 Feb 2019, Accepted: 26 Feb 2019

Published Online: 07 March 2019

In-Text Citation: (Hee \& Rhung, 2019)

To Cite this Article: Hee, O. C., \& Rhung, L. X. (2019). Motivation and Employee Retention among Millennials in Malaysia. International Journal of Academic Research in Business and Social Sciences, 9(2), 876-884.

\section{Copyright: (c) 2019 The Author(s)}

Published by Human Resource Management Academic Research Society (www.hrmars.com)

This article is published under the Creative Commons Attribution (CC BY 4.0) license. Anyone may reproduce, distribute, translate and create derivative works of this article (for both commercial and non-commercial purposes), subject to full attribution to the original publication and authors. The full terms of this license may be seen

at: http://creativecommons.org/licences/by/4.0/legalcode

\section{Vol. 9, No. 2, 2019, Pg. 876 - 884}

Full Terms \& Conditions of access and use can be found at http://hrmars.com/index.php/pages/detail/publication-ethics 


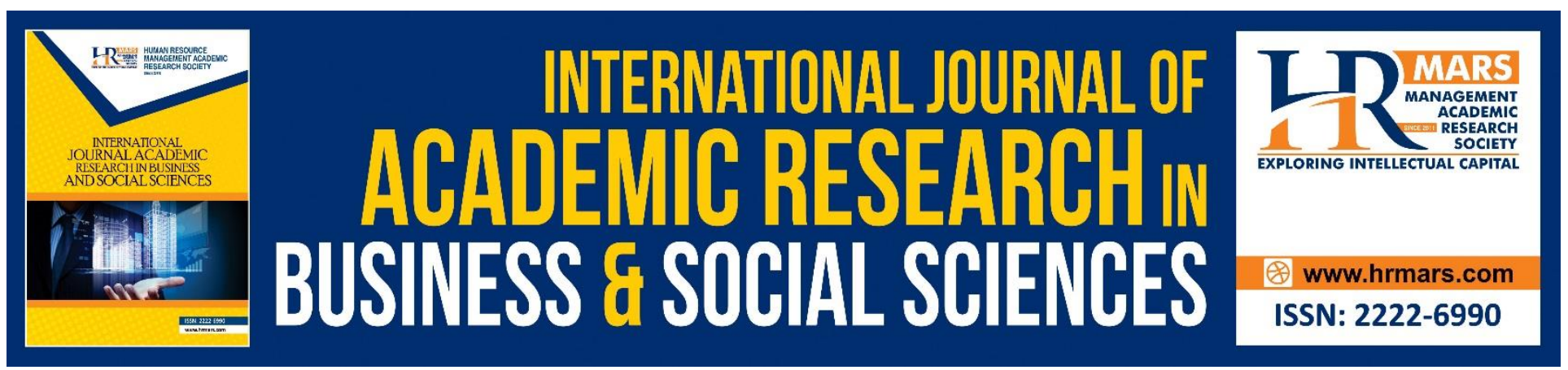

\title{
Motivation and Employee Retention among Millennials in Malaysia
}

\author{
Ong Choon Hee and Loh Xin Rhung \\ Azman Hashim International Business School, Universiti Teknologi Malaysia, Johor, Malaysia. \\ Corresponding Author: ongchoonhee@gmail.com
}

\begin{abstract}
The main thrust of the study is to investigate the factors that motivate millennials at their workplace. The objectives of the research are to determine the relationship between intrinsic and extrinsic motivation that influence employee retention among millennials. The sample for the study consists of millennial employees who are working in the city of Johor Bahru, Malaysia. A quantitative survey approach will be used in this research and questionnaire will be designed and distributed to the millennial workers in Johor Bahru. It is proposed that extrinsic motivation (i.e. compensation, career development, workload, work environment) and intrinsic motivation (i.e. sense of purpose, challenging work, freedom to choose and recognition) will be used as predictors to test against employee retention as the outcome variable of this research.
\end{abstract}

Keywords: Extrinsic Motivation, Intrinsic Motivation, Employee Retention, Millennials.

\section{Introduction}

Employee retention is the common issue and concern for every organization. Turnover has become a common trend and it is not only happen in Malaysia, but around the world. According to Rishesingar Ramasamy, the head of BAE Systems engineering centre in Malaysia, the average turnover is around two and a half years for any individual in any organisation (Yeong, 2017). The non-manufacturing sector showed the highest annual average turnover rate which includes IT and Communication sectors with 75.72\%, Association and Societies with 33\% and Hospitalization sector with 32.4\%, while the manufacturing sector reflected a lower annual average turnover rate such as $23.88 \%$ from basic and fabricated metallic products, $23.04 \%$ from electrical and electronics, and $19.92 \%$ from plastic and rubber industries, as reported by the Malaysian Employers Federation (MEF) (Lisa, 2012). This turnover trend was mostly dominated by Generation Y, or the millennials (Lisa, 2012). Based on a survey by the International Islamic University Malaysia (IIUM), the millennials are not gratified with their income and job situation (Hariati, 2017). They are not only pursuing for money, but also interest, work-life balance, and perhaps flexible working hour or work at home in accordance with the remark 
by Jeannie Khoo, Kelly Services marketing director for Singapore and Malaysia (Lisa, 2012). Even though Generation $X$ is still dominating the workplace especially in the middle and senior management positions, they were followed closely by Generation $Y$, who will eventually replace them when they reach retirement age (Kuek et al., 2015). Malaysia-Australia Business Council Chairman, Leigh Howard mentioned that, Malaysia should adapt to the changes in employment trends as the employment relationship that presented in 50 years ago had disappeared, the talented employees tend to go out and apply their skills in different fields (Yeong, 2017). Millennials are growing in population, with about 2 billion of people globally, which account for around one fourth of the world population. Most of the millennials are located in Asia, with around 410 million in India, 400 million in China, which are far more compared to millennials in Europe and US. In Malaysia, millennials have the proportion of $29 \%$ of the country population (Lin, 2018). Millennials comprise up to $25 \%$ of workforce in Asia Pacific and the number is expected to grow continuously. It is estimated that millennials will make up $50 \%$ of the global workforce by 2020 as reported Jobstreet.com. As the millennials grow in work force, it will eventually replace the position of Generation $X$ and baby boomers. Hence, it is important to find out what are the motivational factors that motivate millennials to retain the workplace.

\section{Employee Retention}

Employee retention concept started to appear in business in the 1970s. Employee retention means the ability of an employer to retain employees in the company (Chandra, 2016). Employee retention is a process to encourage employees to remain in the organization for the maximum period of time (Raminder, 2017). Employee retention is one of the cost saving measures for the company. Retaining existing employees help to save company cost. Employee retention is the important backbone assets for the company. The cost for employee turnover increases the company expenses such as cost for hiring, training new employees and productivity losses. It is difficult to estimate the exact amount for turnover cost. However, industry experts estimated $25 \%$ of an employee salary as a conservative number for a replacement. Besides monetary lost, the resignation of an employee leads to lengthy of time needed for hiring process and training of new employees. Moreover, the efficiency of new employee is yet to be assured. In addition, when an employee resigns, his valuable knowledge about the organization, customers, current projects and experience will be left together with the employee. The investment of the company includes time and money spent on the employee is wasted as the expectation of a future return will not be realised (Prashant \& Megha, 2013). There are three important theoretical models on employee retention. They are Zinger Model, Employee Retention Connection's Model and Integrated System for Retaining Employees (Raminder, 2017). In Zinger Model, employee retention is targeted to achieve a desired result. In order to achieve the result, strategy is needed for the company. Connection or engagement is the central key for employee retention. Powerful recognitions are needed to retain talent. This theory emphasizes that performance management is contributed by employee retention, which engagement and retention improve and boost the company performance. The organization esteem should be built by aligning the employee with the company objectives. Disconnection between employee and organization should not be existed. Company expected a strong relationship between employee engagement and retention, which in return helps to serve the customers effectively. Employees should develop 
personal abilities and professionalism through work to cultivate their strength, visibility and value. Work and task should contribute to employee's well-being. The organization performance are depending on health and productivity of the employee individually (Sultana \& Bushra, 2013). On the other hand, Employee Retention Connection's model stated that stimulating work, leadership, recognition and rewards are the main elements which affect employee retention. Work can be stimulating by giving several assistance such as decision making authority, resources and support, learning opportunities and personal recognition. Motivational leadership encourage leaders to accept changes and open to new ideas. They should provide direction of the organization vision, help others to develop their capabilities and become a model that reflects the organization values. The company should focus on recognition and provide rewards for those do well in their jobs. Success should be appreciated to build self-esteem and enhance companionship and team work (Sultana \& Bushra, 2013). Finally, in integrated system for retaining employees, it stated that employee retention transforms organization culture and enhances competitive edge of the company. The processes of transformation include analysing organization climate, designing stimulating work, training motivational leaders, competency building, career development, recognizing and rewarding performance (Sultana \& Bushra, 2013).

\section{Extrinsic Motivation}

Salary is the most important factor employees in the organization. Bonuses and other fringe benefits are considered having less impact compared to salary (Sudhanshu \& Chauhan, 2013). According to the annual Global Shapers Survey from World Economic Forum (WEF) with more than 30000 respondents with age under 30 across 180 countries, $49.3 \%$ consider that salary is the most important criteria in considering a job (Clarke, 2017). It was observed that majority of the employees would like to switch their jobs if another company is able to offer more salary (Damaris et al., 2016), especially for the Generation Y (Abdelbaset, Yusoff \& Dwaikat, 2015). It is proven that the millennial workers are strongly preferred extrinsic rewards. Their job satisfaction would have adverse effects if these rewards are not sufficient which could encourage them to seek for new job with the better extrinsic rewards. Furthermore, millennials are facing challenges to deal with the increasing living cost and financial commitment. Hence, they will continue to change from one job to another in order to get a better salary. Extrinsic reward is an important factor for millennials to manage rising prices, different life styles and future obligations (Abdelbaset, Yusoff \& Dwaikat, 2015). A good reward system with more benefits and opportunities of rewards will improve the productivity of younger people as they are always looking for development with better opportunities at the workplace (Gupta \& Subramanian, 2014). Career development is another form of extrinsic motivation that will retain employees. It includes promotion and training and development provided by the organization. Promotion and job growth are good motivators which influenced the job performance (Damaris et al., 2016). The employees will work with more efforts and efficiencies if they found that they have a great future in the company (Nabi et al., 2017). When skills are developing with a steady pace, the organization will create a positive work environment with continuous learning culture. Since millennials are fast learner and they are able to master skills quickly, a learning culture will suit their work behaviours. Investment on training and development such as courses and workshops would 
bring more learning opportunities and in return enhancing millennials knowledge and prepare them for promotions. In this case, they will prefer to retain in the organization ( $\mathrm{Ng}$, Schweitzer \& Lyons, 2010). Workload is another key for employees to switch their jobs. Workload means the amount of job or task assigned by the superiors. When a worker feels that his workload is too heavy, he will start to make a change to whether leave the company or changing his attitude or performance at work as he feels that there is no equilibrium in every aspect of his life. Generally, most employees not willing to work more than their job description, which indicated that if a worker is not overloaded with more than their job requirements, they are said to be more committed and the organizational performance could be better (Damaris et al., 2016). Moreover, some of the employees may feel stressful when excessive workloads and responsibilities are assigned to the employee, and this may lead to a demotivation ( $\mathrm{Nabi}$ et al., 2017). Therefore, appropriate workload is imperative in retaining employees at the workplace and definitely not to impose much extra workload after working hours (Abdelbaset, Yusoff \& Dwaikat, 2015). Work environment is also another motivator for employees at the workplace. Work environment includes the organization culture and also the interaction among superiors and co-workers. A positive work environment will lead to a positive and higher employees' performance and reduce turnover (Abdifatah, Odhuno \& Ondabu, 2015). In a good working environment, an employee is able to perform more conveniently and lesser difficulties (Nabi et al., 2017). An open office system lead to a positive effect and it stimulates an interactive working environment with consultation purpose. Free interaction among employees create cohesion and good working climate as everyone is able to work together and no one is left to work alone. It is believed the relationship with superiors and peers will be fostered acts as a motivator for employees to retain in the organization (Nabi et al., 2017). Therefore, based on the above discussion, it is proposed that:

Proposition 1: Extrinsic motivation (i.e. compensation, career development, workload, work environment) has a significant relationship with employee retention.

\section{Intrinsic Motivation}

Intrinsic motivation is factors that come from rewards inherent to a task or activity itself such as the enjoyment and love to do something. This form of motivation has been studied by social and educational psychologists since early 1970s (Sudhanshu \& Chauhan, 2013). The examples of intrinsic motivation include sense of purpose, challenging work, ability to choose, opportunity for career advancement, and recognition. Sense of purpose is one of the key factors for young workers and it influences employee retention. This reflects that the young people care for others and their environment. They would like to learn and grow personally and professionally. All of these showed that young people have a strong social consciousness. According to the Global Shapers Survey by World Economic Forum, sense of purpose was the second important criteria when consider a job (Clarke, 2017). Personal development is very critical for millennials. They expect significant contribution from their employer in this aspect. Hence, corporate social responsibility policy in an organization is a concern for millennial workers, as it indicates the values and ethics of the organization. In addition, eco-friendly environment is also an important criterion as it indicates the social contribution of an organization to the society (Weyland, 2011). Hence, organizations can 
improve their reputation by practicing social responsibilities and attract more millennials to engage and involve in this meaningful and challenging work ( $\mathrm{Ng}$, Schweitzer \& Lyons, 2010). Challenging work is also a concern for millennials as they are hungry for stimulation and they like to be challenged. Millennials would like to take challenges and make a difference to the world. New experiences will always attract the attention of millennials. The philosophy of "job for life" that is last for baby boomers and no longer valid in the millennials' workplace. Millennials will leave the organization once they feel bored and becoming spiritless (Weyland, 2011). They value the work projects that are challenging and developmental in nature. A boring and routine job will be a threat to motivation and retention. Hence, a continual feeling of development and sufficient challenges are important factors to avoid demotivation and turnover (Susanna \& Riitta, 2014). Freedom to choose is another intrinsic motivation for employees. As the employees are given the authority to make decision under their territories of expertise, it will become an enormous motivation for employees. Freedom to choose is important for the millennials when making a decision. However, the decision making authority should be assigned under their expertise and not beyond their capabilities (Nabi et al., 2017). Millennials appreciate flexibility in working hours, work methods and other work arrangement. If they are able to decide their own schedule and organize their own work, they are willing to sacrifice some of their free time to complete the task. And this work autonomy seems to be crucial to motivate them to stay in the workplace (Susanna \& Riitta, 2014). Recognition is another motivation for employees at the workplace. Recognition explains the appreciation and respect earned from the workplace especially from the superiors. Millennials would feel that their effort and works are recognized and worth doing it. It was found that employee retention and the likeness for the work are related with recognition by superiors (Sudhanshu \& Chauhan, 2013). It is important to provide a micro view of the job for the employees so that they understand their daily job contribution towards the external impact and overall success of the organization. Recognition will add value and keep employees to focus on their responsibilities and promote development and progression. Millennials will not deterred by traditional limitations. They will bring in their own methods to carry out their work in a more efficient manner, especially if it involves new technology. Therefore, if their ideas are accepted and recognized, they will very likely to retain in the organization (Weyland, 2011). Therefore, referring to the above discussion, it is proposed that:

Proposition 2: Intrinsic motivation (i.e. sense of purpose, challenging work, freedom to choose, recognition) has a significant relationship with employee retention. 
INTERNATIONAL JOURNAL OF ACADEMIC RESEARCH IN BUSINESS AND SOCIAL SCIENCES

Vol. 9, No. 2, Feb, 2019, E-ISSN: 2222-6990 C 2019 HRMARS

\section{Theoretical Framework}

Based on the write up and previous findings in the literature review, a theoretical framework was developed as presented in Figure 1.

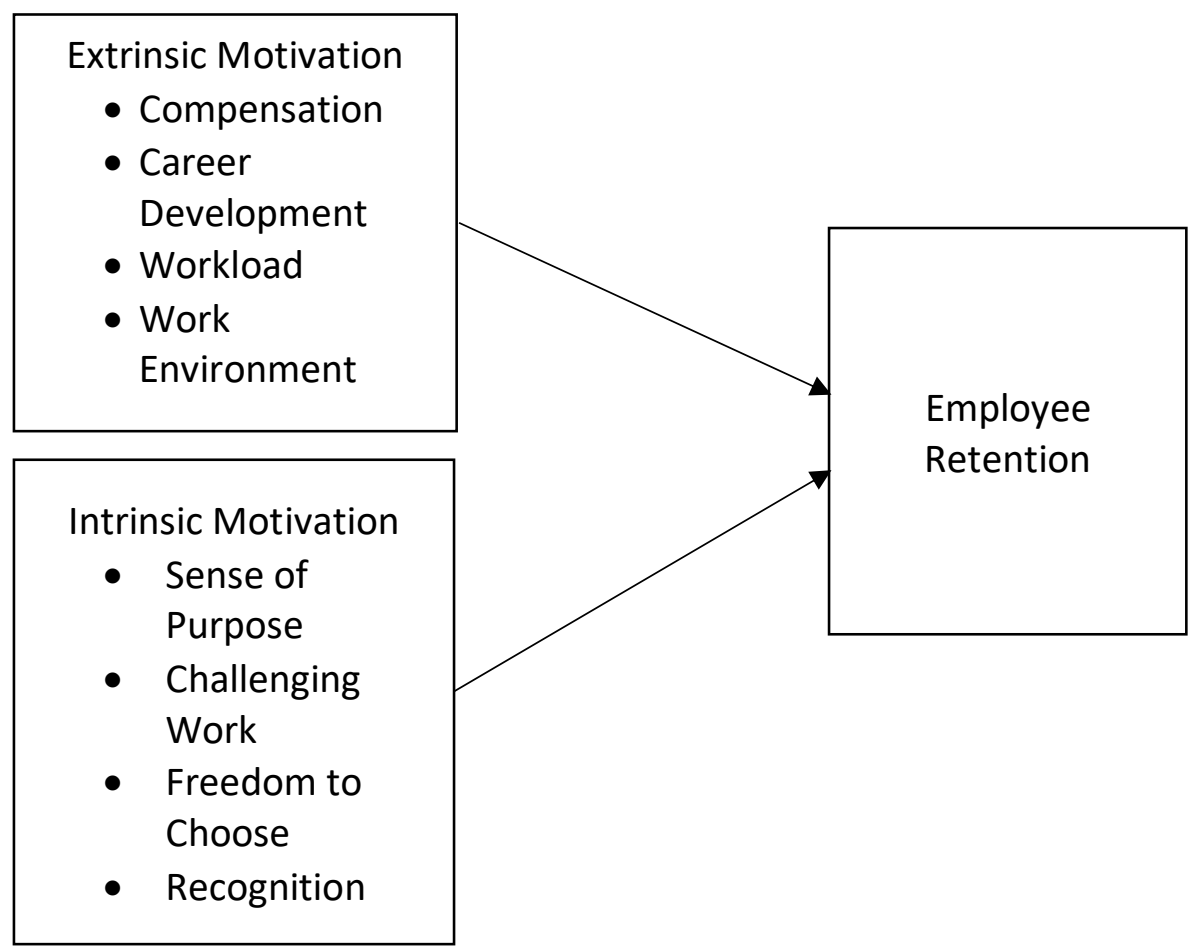

Figure 1: Proposed Theoretical Framework

\section{Research Implications}

As millennial generation start to grow in workplace and baby boomers start to retire, millennials will eventually take up the positions of baby boomers and Generation X. There is a generation gap between these generations, and managers and human resources professionals will need to understand the background and characteristics of every generation (Kuek et al., 2015). In order to develop new engagement models and manage the workforce more effectively (Gilbert, 2011), this study proposes intrinsic and extrinsic motivational factors that motivate employees and the methods to retain talents in the company. This study will serve as a guide for managers to implement programs to retain talents in their organizations. In business, good employees will ensure organization always stays ahead of their competitors and become the leader in the market.

\section{Conclusion}

Although past researches have provided many insights into the factors that influence employee retention, little is known about motivators that influence millennials' retention at the workplace in the Malaysian context. Understanding motivators (i.e. extrinsic and intrinsic) that lead to employee 
INTERNATIONAL JOURNAL OF ACADEMIC RESEARCH IN BUSINESS AND SOCIAL SCIENCES

Vol. 9, No. 2, Feb, 2019, E-ISSN: $2222-6990$ ๑ 2019 HRMARS

retention especially for millennials may help identifying changes needed to be done for managers and organizations in the near future.

\section{Acknowledgements}

The authors would like to thank the Malaysian Ministry of Higher Education and Universiti Teknologi Malaysia (GUP-Vot: 14J81) for providing financial support to publish this paper.

\section{References}

Abdelbaset, Q., Yusoff, W. F. W. \& Dwaikat, N. (2015). Explaining Generation-Y Employees' Turnover in Malaysian Context. Asian Social Science, 11(10).

Abdifatah, A. A., Odhuno, E., Ondabu, I. T. (2015). Analysis of Extrinsic Rewards and Employee Satisfaction: Case of Somtel Company in Somaliland. International Journal of Business Management and Economic Research, 6(6). Retrieved from http://www.ijbmer.com/docs/volumes/vol6issue6/ijbmer2015060609.pdf

Chandra, S. P. (2016). Influence of Retention Policies on Employee Efficiency and Organization Productivity. Managerial Strategies and Practice in the Asian Business Sector. Retrieved from https

://books.google.com.my/books?id=VIVACwAAQBAJ\&pg=PA90\&dq\&source=gbs_selected_page $\mathrm{s} \& \mathrm{cad}=2 \# \mathrm{v}=$ onepage $\& \mathrm{q}=$

Clarke, R. (2017). Millennials value a 'sense of purpose' in work, says World Economic Forum. Retrieved from http://www.hrreview.co.uk/hr-news/millennials-consider-salary-top-prioritychoosing-new-job-says-world-economic-forum/105702

Damaris, K., Gregory, S. N., Elizabeth, N. M., Aloys, K. N. (2016). Determinants of Intrinsic and Extrinsic Rewards on Employee Performance in Kapsara Tea Factory Company Trans Nzoia County Kenya. International Journal of Academic Research in Business and Social Sciences, 6(10). Retrieved from http://hrmars.com/hrmars_papers/Determinants_of_Intrinsic_and_Extrinsic_Rewards_on_Em ployee_Performance_in_Kapsara_Tea_Factory_Company_Trans_Nzoia_County_Kenya.pdf

Gilbert, J. (2017). The Millennials: A new generation of employees, a new set of engagement policies. Retrieved from https://iveybusinessjournal.com/publication/the-millennials-a-new-generationof-employees-a-new-set-of-engagement-policies/

Gupta, B., Subramanian, J. (2014). Factors Affecting Motivation among Employees in Consultancy Companies. International Journal of Engineering Science Invention, 3(11).

Hariati, A. (2017). The angst of their generation. Retrieved from https://www.thestar.com.my/news/nation/2017/05/28/the-angst-of-their-generation-for-themillennials-fretting-about-their-material-wellbeing-perhaps-it/

Kuek, T. Y., Choong, A. Y. O., Tan, P. S. H. (2015). Managing Gen Y. Retrieved from https://www.thestar.com.my/news/education/2015/06/07/managing-gen-y/

Lisa. (2012). Why job-hoppers hop. Retrieved from https://www.thestar.com.my/news/nation/2012/02/19/why-jobhoppers-hop/

Nabi, M. N., Islam, M. M., Tanvir, M. D., Hossain, M. A. A. (2017). Impact of Motivation on Employee Performances: A Case Study of Karmasangsthan Bank Limited, Bangladesh. Arabian Journal of Business and Management Review, 7(1). Retrieved from https://www.omicsonline.org/open- 
INTERNATIONAL JOURNAL OF ACADEMIC RESEARCH IN BUSINESS AND SOCIAL SCIENCES

Vol. 9, No. 2, Feb, 2019, E-ISSN: 2222-6990 C 2019 HRMARS

access/impact-of-motivation-on-employee-performances-a-case-study-of-karmasangsthanbank-limited-bangladesh-.pdf

Ng, E. S. W., Schweitzer, L., Lyons, S. T. (2010). New Generation, Great Expectations: A Field Study of the Millennial Generation. Journal of Business Psychology, 25.

Prashant, S. W., Megha, R. P. (2013). Retention Management: A Tools towards Organizational Development. 1st National Conference on "Dynamism in Management. Special Issue of International Journal of Engineering, Economics and Management. Retrieved from http://ijeem.org/Papers/Speciallssue2013/Retention\%20Management\%20A\%20Tools\%20Towa rds\%200rganizational\%20Development.pdf

Raminder, K. (2017). Employee Retention Models and Factors Affecting Employees Retention in IT Companies. International Journal of Business Administration and Management, 7(1). Retrieved from https://www.ripublication.com/ijbamspl17/ijbamv7n2spl_15.pdf

Sudhanshu, B., Chauhan, S. S. (2013). A Critical Analysis on Intrinsic \& Extrinsic Factors of Motivation. International Journal of Management \& Business Studies, 3(3). Retrieved from http://www.ijmbs.com/33/garima.pdf

Sultana, N., Bushra, B. (2013). Employee Retention Practices in India Corporate - A Study of Select MNCs. International Journal of Engineering and Management Sciences, 4(3). Retrieved from http://scienceandnature.org/IJEMS-Vol 4(3)-July2013/IJEMS_V4(3)2013-14.pdf

Susanna, K., Riitta, L. V. (2014). Sufficient challenges and a weekend ahead - Generation Y describing motivation at work. Journal of Organizational Change Management, 27(4)

Weyland, A. (2011). Engagement and talent management of Gen Y. Industrial and Commercial Training, 43(7).

Yeong, E. (2017). Average job turnover for a person is $2 \frac{1}{2}$ years. Retrieved from http://www.thesundaily.my/news/2017/07/20/average-job-turnover-person-2\%C2\%BD-years 